\title{
Heritable differences in chemosensory ability among humans
}

\author{
Richard D Newcomb $b^{1,2,3}$, Mary B Xia ${ }^{4}$ and Danielle R Reed ${ }^{4 *}$
}

\begin{abstract}
The combined senses of taste, smell and the common chemical sense merge to form what we call 'flavor.' People show marked differences in their ability to detect many flavors, and in this paper, we review the role of genetics underlying these differences in perception. Most of the genes identified to date encode receptors responsible for detecting tastes or odorants. We list these genes and describe their characteristics, beginning with the best-studied case, that of differences in phenylthiocarbamide (PTC) detection, encoded by variants of the bitter taste receptor gene TAS2R38. We then outline examples of genes involved in differences in sweet and umami taste, and discuss what is known about other taste qualities, including sour and salty, fat (termed pinguis), calcium, and the 'burn' of peppers. Although the repertoire of receptors involved in taste perception is relatively small, with 25 bitter and only a few sweet and umami receptors, the number of odorant receptors is much larger, with about 400 functional receptors and another 600 potential odorant receptors predicted to be non-functional. Despite this, to date, there are only a few cases of odorant receptor variants that encode differences in the perception of odors: receptors for androstenone (musky), isovaleric acid (cheesy), cis-3-hexen-1-ol (grassy), and the urinary metabolites of asparagus. A genome-wide study also implicates genes other than olfactory receptors for some individual differences in perception. Although there are only a small number of examples reported to date, there may be many more genetic variants in odor and taste genes yet to be discovered.
\end{abstract}

Keywords: Flavor, Genetics, Evolution, Taste, Odor, Receptor, Polymorphism

\section{Review}

\section{Why we differ in taste perception}

Humans use several kinds of information to decide what to eat, and the combination of experience and sensory evaluation helps us to choose whether to consume a particular food. If the sight, smell, and taste of the food are acceptable, and we see others enjoying it, we finish chewing and swallow it. Several senses combine to create the idea of food flavor in the brain. For example, a raw chili pepper has a crisp texture, an odor, a bitter and sour taste, and a chemesthetic 'burn.' Each of these sensory modalities is associated with a particular group of receptors: at least three subtypes of somatosensory receptors (touch, pain, and temperature), human odor receptors, which respond either singly or in combination; $[1,2]$, at least five types of taste receptors (bitter, sour, sweet, salty, and umami (the savory experience associated with

\footnotetext{
* Correspondence: reed@monell.org

${ }^{4}$ Monell Chemical Senses Center, Philadelphia, PA 1014 USA

Full list of author information is available at the end of the article
}

monosodium glutamate [3])), and several families of other receptors tuned to the irritating chemicals in foods, especially of herbs and spices (for example, eugenol found in cloves [4] or allicin found in garlic [5]). The information from all these receptors are transmitted to the brain, where it is processed and integrated [6]. Experience is a potent modifier of chemosensory perception, and persistent exposure to an odorant is enough to change sensitivity [7].

\section{Variants of the bitter taste receptor gene TAS2R38}

Each person lives in a unique flavor world, and part of this difference lies in our genetic composition, especially within our sensory receptors [8]. This idea is illustrated by bitter perception and bitter receptors. The bitter receptor family, TAS2, has approximately 25 receptors, found at three locations in the human genome $[9,10]$. We say 'approximately' because bitter receptors have copy number variants [11], and it is currently unclear at what point a recently duplicated gene should be assigned

\section{Ciomed Central}


a distinct name. This conundrum is more than a mere matter of record-keeping; the bitter receptor gene copy number is a source of biological variation and may affect perception, although this prospect has not yet been established empirically.

The first demonstration that genetic variants contribute to person-to-person differences in human taste perception was for the bitter receptor TAS2R38 (Table 1). It has been known since 1931 that some people are insensitive to the bitter compound phenylthiocarbamide (PTC), a chemical that was synthesized by Arthur Fox for making dyes. While he was working in his laboratory, Fox accidentally tasted the compound and found it bland, yet when his benchmate also accidentally tasted the compound, he found it very bitter [12]. This observation contributed to the formation of a hypothesis, now widely accepted, that there is a family of bitter receptors, at least one of which is sensitive to this compound, but is inactive in some people.

In 2003, this hypothesis was tested using genetic linkage analysis. Relatives such as parents and children were assessed for their ability to taste PTC and for their pattern of DNA sharing. The genomic region most often shared by relatives with similar tasting ability was near the TAS2R38 gene [26], but this evidence in itself was insufficient to conclude that the TAS2R38 gene was responsible for this sensory trait. Genes encoding bitter taste receptors are physically clustered on chromosomes, and nearby DNA regions tend to be inherited together, so it was not clear whether TAS2R38 or a neighboring receptor was the responsible gene. This issue was resolved later, when individual bitter receptors were introduced into cells without taste receptors. Only those cells that contained the TAS2R38 gene responded to PTC. Moreover, cells containing naturally occurring genetic variants of the TAS2R38 gene from people who could not taste PTC were also unresponsive to this bitter compound [13]. Together, these data showed that TAS2R38 and its variants explained the inability of some people to taste PTC at concentrations at which it is readily detectable to others.

The inability to taste PTC as bitter can be considered a categorical trait (either people can taste it or they cannot), and can also be considered a quantitative trait, that is, as a continuum, but with most people falling at either end [27]. This quantitative feature is explained by the pattern of genetic variants in the receptor. Two main forms determine the categorical trait (the extremes of tasting or not tasting), and each is made up of changes to predicted amino acids. The AVI variant (with alanine at position 49 , valine at 262 , and isoleucine at 296) is the non-tasting form, whereas the PAV variant (with proline at 49 , alanine at 262, and valine at 296) is the tasting form. There are other haplotypes within the gene, and these give rise to intermediate phenotypes and thus explain the quantitative trait $[13,26,28]$. (By way of explanation, a 'haplotype' is the order of genetic variants along each chromosome; in the above example, 'AVI' is one haplotype and 'PAV' is another.) An intriguing observation is that heterozygotes (people with one taster and nontaster form of the receptor) can differ markedly in taste ability (Figure 1). All subjects gave informed consent and the protocol was approved by the Institutional Review Board of the University of Pennsylvania. This observation indicates that some people may naturally express more of either the tasting or non-tasting form

Table 1 Genes associated with variation in taste and olfactory ability in humans

\begin{tabular}{|c|c|c|c|}
\hline Gene & Polymorphisms & Taste/odor & Reference/s \\
\hline \multicolumn{4}{|l|}{ Taste } \\
\hline TAS2R38 & P49A, A262V, V296I & Phenylthiocarbamide (PTC) & {$[13,14]$} \\
\hline TAS2R31 & C103T, R35W & Saccharin, acesulfame K & {$[11,15]$} \\
\hline TAS2R19 & $\mathrm{R} 299 \mathrm{C}^{\mathrm{a}}$ & Quinine & {$[14]$} \\
\hline TAS1R3 & Promoter SNPs at -1266 and 1572 & Sucrose & {$[16]$} \\
\hline GNAT3 & Promoter SNP at $-10127^{a}$ & Sucrose & {$[17]$} \\
\hline TASIR1 & T372A, R757C & Monosodium glutamate & {$[18]$} \\
\hline \multicolumn{4}{|l|}{ Olfaction } \\
\hline OR7D4 & $\mathrm{R} 88 \mathrm{~W}, \mathrm{~T} 133 \mathrm{M}$ & Androstenone & {$[19,20]$} \\
\hline OR11HTP & $\mathrm{Q} 227^{\mathrm{C}} \mathrm{b}$ & Isovaleric acid & {$[21]$} \\
\hline OR2J3 & T113A, R226Q & Cis-3-hexen-1-ol & {$[22,23]$} \\
\hline$O R 2 M \nearrow^{C}$ & ND & Metabolites of asparagus & {$[24,25]$} \\
\hline
\end{tabular}

$\mathrm{ND}$, not determined.

${ }^{\mathrm{a}}$ Best associated single-nucleotide polymorphism (SNP) but not necessarily causal.

${ }^{\mathrm{b}}$ Nonsense mutation.

${ }^{\mathrm{c} C l o s e s t}$ olfactory receptor gene. 


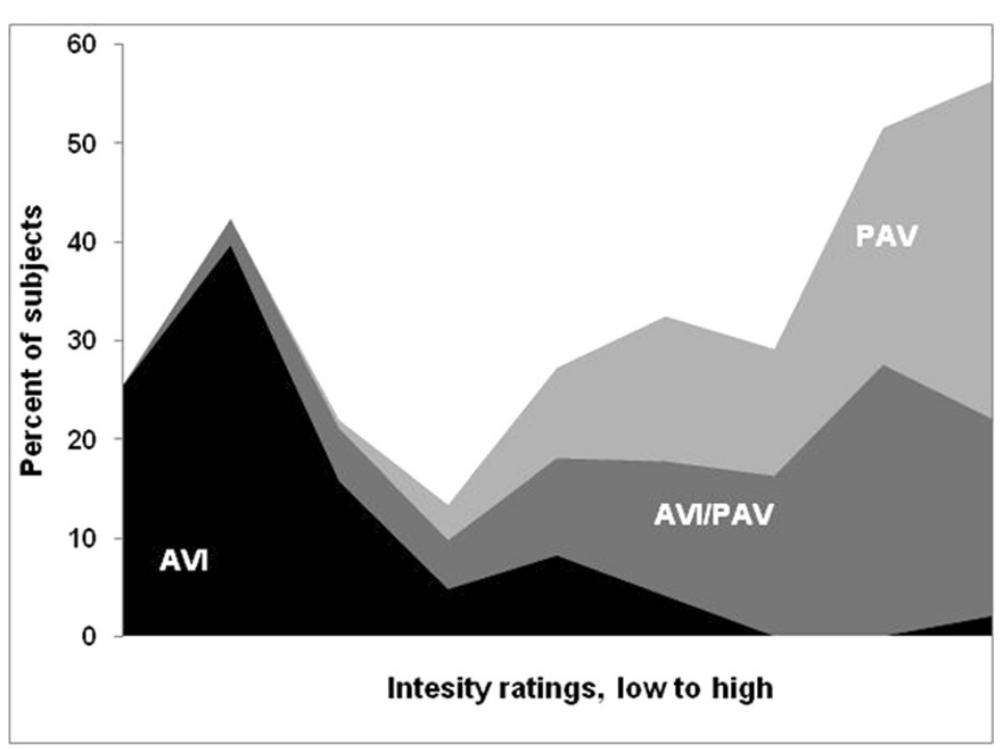

Figure 1 Ratings of bitter intensity by subjects with one of three TAS2R38 diplotypes. Subjects were grouped by genetic variant, either AVI (alanine, valine, isoleucine) or PAV (proline, alanine, valine), AVI (AVI/AVI, $n=146)$ are shown in in solid black; AVI/PAV $(n=265)$ in medium grey, and PAV (PAV/PAV; $n=108$ ) light grey). The observations were grouped into bins by intensity rating, and are expressed as the percentage of subjects. For example, subjects to the left rated PTC as not intense at all, and were more likely to have the AVI/AVI genotype.

(that is, differential regulation of allele expression or protein translation).

Not all variation in the perception of PTC can be accounted for by nucleotide variants within the TAS2R38 gene. A few people do not fit this pattern; for instance, those with two copies of the non-tasting form, who report they can taste intense bitterness of PTC [13] (Figure 1). This may be explained by unknown variants in the TAS2R38 receptor that increase its function. It is also possible that the non-tasting form is 'rescued' by other bitter receptors or by other types of genes [29-31]. However rescue must be rare, because genome-wide association studies detect no additional phenotype-phenotype associations $[14,32]$.

Although the genetics of taste perception has been dominated by the study of PTC and its effects, evidence is gradually accumulating that the ability (or inability) to perceive other bitter tastes is heritable. For example, identical twins, who have identical genetics, are more similar in their perception of bitter compounds (other than PTC) than are fraternal twins, who are no more similar genetically than siblings [33]. A variant in a cluster of bitter receptors on chromosome 12 is associated with quinine perception [14], and the bitterness of some high-intensity sweeteners is associated with alleles within a cluster of bitter receptors on chromosome 12 [11]. These observations suggest that individual differences in bitter perception may be common, and are related to genotype.

Bitterness is a part of human life in two ways, in food and in medicine. In general, humans tend to avoid bitter foods; in a study by Mattes [34], nearly half of people surveyed ate no bitter foods at all. When these subjects were asked to consume a bitter solution, they diluted it with water until the bitterness could no longer be detected [34]. Other common methods to reduce bitterness include cooking [35], or the addition of salt [36,37] or flavors [38], but bitterness is not an inevitable part of life for everyone. To illustrate this point, when we asked 8 people to rate 23 vegetables for bitterness intensity, we found that some people were insensitive to even the most bitter vegetables (Figure 2). Of course, people who are sensitive to the bitterness of a particular vegetable or other food can avoid eating it.

Bitter-sensitive people can choose what they eat to avoid unpleasantness but cannot as easily avoid bitter medicines. Humans have developed strategies to improve the taste of medicine, such as adding sugar [39], and although such methods help, they are not perfectly effective [40]. The problem of bitter taste in medicines may be especially troubling for people with inborn bitter sensitivity. For instance, children who are genetically more sensitive to some types of bitter molecules are also more likely to take medicines in pill rather than liquid form, perhaps because liquids are more unpleasant than pills, which are often encapsulated or coated [41].

Why do such differences in bitter perception exist at all? Overall, the DNA sequences of bitter receptors change faster than those of most other genes, especially within the regions of the receptor likely to bind the bitter molecules [42-44], but there are exceptions to this 


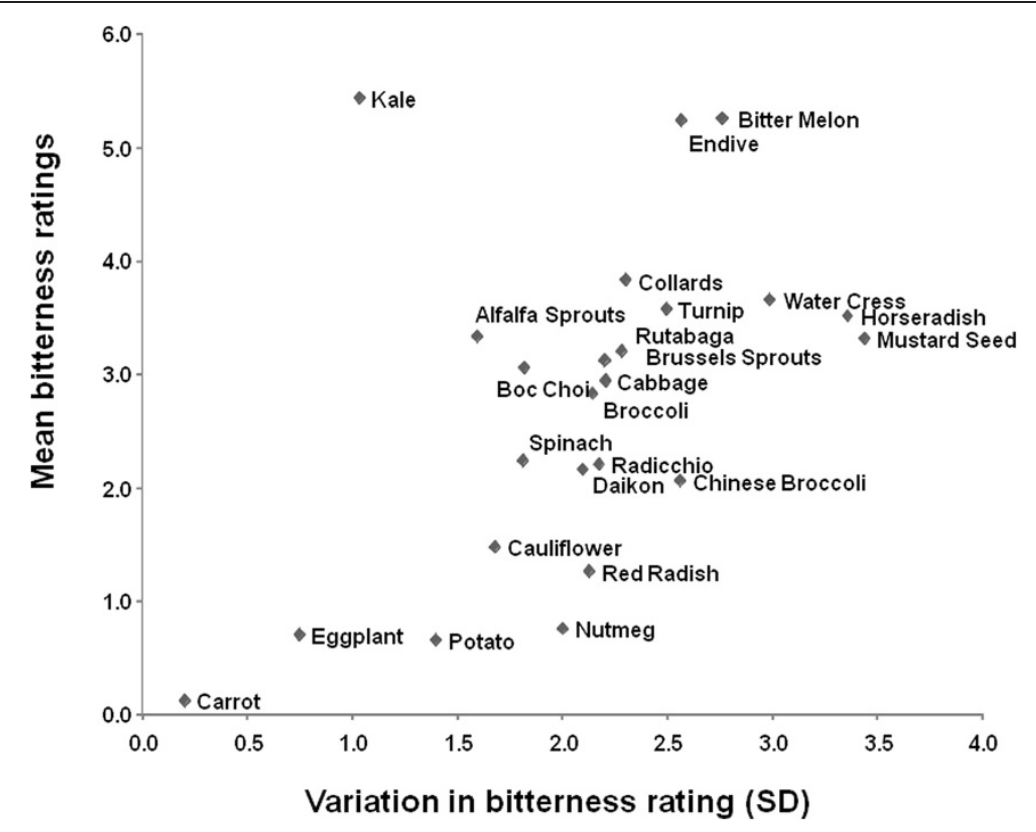

Figure 2 Ratings of bitterness on a 7.5-cm visual analog scale. Subjects rated raw, chopped vegetables for their bitterness. The $y$-axis is the average rating of bitterness for each vegetable and the $x$-axis is the variation between subjects as measured by standard deviation. The more bitter the vegetable tasted on average, the more variable the bitterness ratings $(r=0.497)$.

rule, and a few bitter receptor family members retain an identical DNA sequence over long periods [45]. Thus genetic variation in the population reflects this evolutionary flux. What drives the change in some receptors while others are protected? It could be that there are two or three subtypes of bitter receptors, some of which are more important for taste and food intake, others for digestion, and still others for pathogen defense [46-51]. The degree of variation within the receptor might reflect the different patterns of selective pressure, changing with the labile environment or staying the same to defend against consistent threats.

\section{Genetic differences in sweet taste detection}

The sweet receptor was discovered in parts, with the last part identified in 2001 (Table 1) [52]. This receptor consists of two proteins, T1R2 and T1R3, which form a heterodimer. Humans are attracted to sweetness, and economic and political history has been shaped by the desire to obtain sweeteners in larger and larger quantities $[53,54]$, but not everyone prefers the same amount of sweetness in a given food or drink. Genetic studies suggest that people vary in their liking for sweetness $[8,55,56]$. How this variation arises is poorly understood, but is likely to be due, at least in part, to allelic variation in the sweet receptor [16,57]. The liking or dislike for high-intensity sweeteners (rather than sugars) may be due to their off-tastes; in fact, alleles in bitter receptors partially account for person-to-person differences in how these non-sugar sweeteners are perceived $[11,15,58]$.

Bitter and sweet tastes share some biology in common. There are several shared downstream signaling molecules for bitter and sweet stimuli, such as gustducin [59]. Alleles of human gustducin affect sweet perception [17] and may affect bitter perception but, as yet, this relationship has not been investigated. In addition, whether genetic variation in other common downstream molecules affects sweet and bitter perception is not known.

Although the role of genetic variation in sweet perception among different people is poorly understood, greater progress has been made by examining sweet perception (as inferred from preference data) in other species. All data thus far support the idea that sweet receptors are fine-tuned to an animal's food niche. For instance, carnivorous mammals, which eat no sweet food, have an inactivated form of the sweet receptor $[60,61]$, and some herbivorous animals, which eat no meat, have lost their amino acid receptor [62]. Likewise, animals that swallow their food whole have major taste loss [63]. However, at least one mystery remains. Some primates, including humans, perceive aspartame as sweet, but aspartame is synthetic and does not occur naturally in foods, therefore it is unclear why humans have a receptor for it [64]. 


\section{Differences in umami, sour, and salty taste detection}

The three remaining classic taste qualities, umami, sour, and salty, have been less studied from a genetics perspective compared with bitter and sweet. The taste word 'umami' connotes the quality best exemplified by monosodium glutamate. Some people cannot taste umami $[65,66]$, perhaps due in part to genetic variants within its receptor, TAS1R1 (taste receptor type 1 member 1 ), a heterodimer composed of T1R1 and T1R3, two proteins of the TAS1R family (Table 1 ) [18,67-71]. In addition to this receptor, glutamate may also be sensed by receptors similar to those that recognize glutamate in the brain [72].

People also differ in the perception of sour, and the results of twin studies suggest that is partly due to additive genetic effects [73,74]. The molecular identity of receptors sensing sour taste is still uncertain, so candidate gene association studies are difficult to interpret [75].

Humans perceive sodium and potassium chloride as salty, and how these salts trigger a signal from taste receptor cells to the brain is not known. The sodium channel epithelial $\mathrm{Na}+$ channel $(\mathrm{ENaC})$ and its subunits are implicated in salt perception in mice and rats [76], but the evidence supporting the involvement of this gene and its protein products in human salt perception is equivocal [77]. Genetic studies of threshold for sodium chloride suggest little genetic involvement [74,78], but studies of intensity ratings of concentrated solutions have shown a moderate degree of heritability (Knaapila et al., submitted).

\section{'New' taste qualities and the chemical sense}

Besides bitter, sweet, umami, sour, and salty, several new taste qualities have been identified, such as the taste of minerals, which may arise from the TRPV1 (transient receptor potential cation channel subfamily $\mathrm{V}$ member 1 ) receptor $[79,80]$ or the taste of calcium, arising from a heterodimer of T1R3 and the calcium-sensing receptor [81]. Humans also perceive chemicals such as menthol (cool) or capsaicin (chili hot). These are plant defense compounds, but humans can tolerate and even like them. No heritability has been detected for these as of yet, except for the observation that genetically identical twins are alike in their preference for spicy foods [82]. Finally, there is another class of chemicals in foods that is sensed by cells in the mouth, the fat 'taste' receptor(s). The idea of a special taste for fat, called pinguis, is an old concept [83], made new by the discovery of several membranebound proteins that are essential for the recognition and ingestion of fat [84-87]. Gene knockout studies in mice $[88,89]$ suggest that inactivating mutations in humans are likely to have an effect on human oral fat perception [90]. Recently, variants of the putative lipid receptor CD36 have been associated with differences in oral fat perception
$[91,92]$. In addition, some heritable variation for the textural quality 'astringency' has been identified [93].

\section{Why people differ in odor preferences}

People vary in their ability to smell many volatile compounds. Amoore et al. [94] identified a number of odorants for which a proportion of the population has a diminished ability to smell, including sweaty, malty, urinous, and musky-smelling compounds [94]. More recently, Plotto et al. [95] found that the human population could be divided into those who could and could not smell the pleasant, floral compound $\beta$-ionone [95]. Interestingly, variation in the ability to detect the very similar compound $\alpha$-ionone was much narrower, with no discernible groups of smellers and non-smellers.

Based on what we know from bitter taste, we might expect that differences in the human ability to smell certain compounds relate to variation in genes that encode odorant receptors. However, unlike the taste receptor families, the odorant receptor gene family is very large, with about 400 odor receptor genes found in clusters across the genome $[96,97]$. In fact, this gene family is the largest in the human genome, as it is in all mammalian genomes characterized to date. Many mammals, including mice and dogs, have approximately 1000 odorant receptor genes and the human genes would reach a similar number if another 600 genes that are predicted to be non-functional were included $[98,99]$. It may be that humans, like other primates, began losing functional odorant receptors during the development of tricolor vision when the sense of sight began to dominate [100]. Many pseudogenes segregate within human populations; that is, some people carry at least one active version of the gene, whereas others have inactive forms that render them unable to detect the compound [21].

\section{Four known cases of odorant receptor variants}

Even with only 400 functional odorant receptors, humans are thought to be able to detect hundreds of thousands of different odors. Only a few receptors have been studied for the odors they can detect [101], and many of these receptors seem to be broadly tuned, being able to detect many different compounds, but with different affinities for different odors. To date, only four volatile compounds have been studied for genetic variation associated with differences in perception: the steroid hormone derivative androstenone (musky), isovaleric acid (cheesy), cis-3-hexen-1-ol (grassy), and metabolites of asparagus found in urine (sulfurous or cabbage-like). In most cases, the associated genetic variant(s) falls within or close to genes encoding odorant receptors (Table 1). The question of why there are so few cases of genetic associations is interesting to consider, especially given the large number of receptors present in the 
genome. It may simply be due to the early stage of the research in this area, or it may reflect the redundancy among receptors caused by their overlapping range of activating odors. Other explanations are the technical challenges of determining person-to-person differences in the DNA sequence of olfactory receptors, which can be very similar to one another, and are prone to duplication or deletion. Time and additional research will no doubt tell.

From a genetics perspective, PTC is the best-studied taste stimulus and there is a corresponding best-studied stimulus for olfaction. Human subjects vary considerably in their perception of the testosterone-derived steroidal odor androstenone. This compound is a pheromone in pigs, and is responsible for the negative trait known as 'boar taint' in bacon. Some describe androstenone as unpleasantly sweaty, whereas others think it pleasant and perfume-like, and others cannot detect it at all. Using a cell-based assay to screen 335 receptors, Keller et al. [19] identified the odorant receptor OR7D4 as giving the strongest response to androstenone [19]. Furthermore, OR7D4 responded only to androstenone and the related compound androstadienone, and not to 62 other odorants tested. Keller et al. [19] found four amino acid variants within the OR7D4 receptor that affect sensitivity to the two steroidal odors, with the two common variants (R88W and T133M) being in complete association (linkage disequilibrium; LD). LD refers to the idea that two genetic variants physically close to each other tend to be inherited together. Subjects carrying two copies of the R88/T133 OR7D4 alleles (homozygotes) had high sensitivity for the two compounds, compared with subjects carrying only one copy (heterozygotes). Furthermore, subjects who were homozygous for R88/T133 rated the odors as more intense than did subjects with the other genotypes, and the R88/T133 heterozygotes were more likely to rate androstenone as pleasant-smelling than were the R88/T133 homozygotes. These data provide evidence that variation in OR7D4 affects sensitivity and perception of androstenone and androstadienone, and this observation was recently confirmed for androstenone in an independent sample [20].

Menashe et al. [21] investigated the associations between the ability to detect four odorants (isoamyl acetate, isovaleric acid, L-carvone, and cineole) and genetic variation within 43 odorant receptor genes thought to be segregating for functional and non-functional forms. There was a significant association between the ability to detect isovaleric acid and the segregating odorant receptor pseudogene OR11H7P. People who carry two copies of the defective form of OR11H7P are less likely to be able to detect the cheesy smell of isovaleric acid.

The compound cis-3-hexen-1-ol, which smells of freshly cut grass, is a flavor compound for foods, including many fruits and vegetables, beverages such as white wine, and processed foods, where it is added to promote a fresh flavor note. Jaeger et al. [22] used a genome-wide association approach to identify genetic variants associated with the ability to detect cis-3-hexen-1-ol, and identified a region on chromosome 6 that contains 25 odorant receptor genes [22]. The odorant receptor OR2J3, is able to respond to cis-3-hexen-1-ol, as are two other receptors with neighboring genes, OR $2 W 1$ and OR2J2. However, OR2J3 contains the variants best associated with the ability to detect the compound. In fact, either of two amino acid substitutions within OR2J3, T113A and R226Q, impair the ability of the receptor to detect the grassy smell. When they occur together, as is typically the case, they abolish the ability of the receptor to detect cis-3-hexen-1-ol at all [23].

After the ingestion of asparagus, the urine can take on a distinct smell in some but not all people; either they do not produce or do not detect the odorous asparagus metabolites. A large genetic-association study conducted by a company providing direct-to-consumer genetics testing and web-based questionnaires added the ability to detect this odor as one of the 22 traits examined [24]. Participants were genotyped at more than 500,000 genetic variation sites across their genome, and then associations were tested between these genetic variants and whether the participant had detected the odor. A significant set of associations was found within the OR2M7 gene on chromosome 1 . This gene lies within a cluster of approximately 50 odorant receptors genes. Pelchat et al. [25] replicated the association with OR2M7 by directly determining the ability of participants to distinguish the odor [25]. However, some of the odors detected by the OR2M7 receptor itself have been identified in cellbased assays, such as geraniol and (-)- $\beta$-citronellol [101], which have the smell of geraniums and citrus, respectively, making it less likely that OR2M7 might also detect the structurally unrelated sulfurous compounds typically attributed to asparagus metabolites, such as methanethiol and dimethyl sulfide. Instead, nearby receptors may be responsible.

Not all genetic variation that affects olfaction may arise from receptors. Specific genetic syndromes that affect the development of the olfactory epithelium and cortex reduce or eliminate the sense of smell [102], and it is possible that there may be less serious forms of these disorders that fail to rise to the level of a disease diagnosis, but nonetheless affect olfactory function. There may also be genes that contribute to hyposmia which are not associated with other symptoms or syndromes [103]. Recently a region of the genome that is not near olfactory receptors was implicated in androstenone perception, and further 
characterization of this association may point to novel olfactory genes [20].

\section{Beyond the receptor}

Most of the known gene variations relating to perceptual differences in taste and smell are specific to a single receptor. It may be that receptor variation affects only the perception of its ligand or it may have broader effects due to brain rewiring (in response to missing input) or to the clustering of receptor variants (LD). Thus, more characterization of human perceptual differences in conjunction with genotype studies is needed. The reduced ability to detect a single compound (such as PTC) might be associated with a reduced ability to detect structurally unrelated bitter compounds or even other taste qualities. Variation in genes other than receptors may also have a broad effect on chemosensory perception; for instance, alleles of gustducin may affect both bitter and sweet perception.

\section{Conclusion}

Humans each live in a unique flavor world in part because of their personal pattern of sensory receptors. A prime example is the ability to taste the bitter compound PTC, which relates to taster and non-taster genetic variants for TAS2R38, the gene coding its receptor. Bitter and sweet tastes shares some biology in common; however, unlike bitter, sweet is universally liked, although people differ in how much sweetness they prefer, for reasons not yet known. The umami, sour, and salty taste qualities have been less studied from a genetics perspective, but they too show variation that relates to heritability. Other taste qualities are beginning to be recognized: the taste of calcium, the fat 'taste' (pinguis), and textures such as astringency, in addition to chemicals such as menthol (cool) or capsaicin (chili hot) that excite the common chemical sense. While the repertoire of receptors involved in taste perception is relatively small, with 25 bitter and a few sweet and umami receptor subunits, the number of odorant receptors is large, with 400 functional receptors and another 600 predicted to be non-functional. Odor perception also displays genetic variation, as illustrated by the four known cases of odorant receptor variants related to the perception of androstenone, isovaleric acid, cis-3-hexen-1-ol, and asparagus metabolites. Many more genes that are yet to be discovered may be involved in encoding variants in taste and especially odor detection. The tools allowing this research are now accessible and affordable, and we expect many more associations to be identified in the coming years. A goal of much of the sensory research we review here is to bring the knowledge of genetic variations in the ability to taste and smell specific compounds into the practical world of improving food choices. These studies also give a platform to explore how genotype and experience may interact, making some people more flexible and others less so in their food preferences. In due course, this knowledge may help us adapt foods to specific individuals or genetic groups.

\section{Abbreviations}

LD: Linkage disequilibrium; PTC: Phenylthiocarbamide.

\section{Competing interests}

The authors declare that they have no competing interests.

\section{Acknowledgements}

This work was supported in part by grants from the National Institute of Health Institute of Deafness and other Communication Disorders (P30DC0011735), the New Zealand Ministry of Science and Innovation (C06X0805), and from funds from the Henry and Camille Dreyfus Foundation. From the Monell Chemical Senses Center, we gratefully acknowledge the assistance of Anna Lysenko, Liang-Dar (Daniel) Hwang, Brad Fesi, Alexis Burdick Will, Amanda McDaniel, Kirsten Mascioli, Fujiko Duke, and Rebecca James for the genotyping. Jeremy McRae, Sara Jaeger, Sarah V Lipchock, Gary L Beauchamp, and Michael G. Tordoff provided comments on this manuscript before publication. We would like to thank Wolfgang Meyerhof, Sara Jaeger, Roger Harker, Xia Li, Antti Knaapila, Joseph Brand, Marcia Levin Pelchat, Charles Wysocki, Julie A Mennella, and Scott Stein for useful discussions.

\section{Author details}

${ }^{1}$ The New Zealand Institute for Plant \& Food Research Institute Limited, Auckland, New Zealand. ${ }^{2}$ School of Biological Sciences, University of Auckland, Auckland, New Zealand. ${ }^{3}$ The Allan Wilson Centre for Molecular Ecology and Evolution, Auckland, New Zealand. ${ }^{4}$ Monell Chemical Senses Center, Philadelphia, PA 19014 USA.

\section{Authors' contributions}

RDN and DRR wrote the review with the assistance of MBX. All authors read and approved the final manuscript.

Received: 28 February 2012 Accepted: 16 May 2012

Published: 16 May 2012

\section{References}

1. Buck $L$, Axel R: A novel multigene family may encode odorant receptors: a molecular basis for odor recognition. Cell 1991, 65:175-187.

2. Malnic B, Hirono J, Sato T, Buck LB: Combinatorial receptor codes for odors. Cell 1999, 96:713-723.

3. Yarmolinsky DA, Zuker CS, Ryba NJ: Common sense about taste: from mammals to insects. Cell 2009, 139:234-244.

4. Xu H, Delling M, Jun JC, Clapham DE: Oregano, thyme and clove-derived flavors and skin sensitizers activate specific TRP channels. Nat Neurosci 2006, 9:628-635.

5. Bautista DM, Movahed P, Hinman A, Axelsson HE, Sterner O, Hogestatt ED, Julius D, Jordt SE, Zygmunt PM: Pungent products from garlic activate the sensory ion channel TRPA1. Proc Natl Acad Sci USA 2005, 102:1224812252.

6. de Araujo IE, Rolls ET, Kringelbach ML, McGlone F, Phillips N: Taste-olfactory convergence, and the representation of the pleasantness of flavour, in the human brain. Eur J Neurosci 2003, 18:2059-2068.

7. Wysocki CJ, Dorries KM, Beauchamp GK: Ability to perceive androstenone can be acquired by ostensibly anosmic people. Proc Natl Acad Sci USA 1989, 86:7976-7978.

8. Reed DR, Tanaka T, McDaniel AH: Diverse tastes: genetics of sweet and bitter perception. Physiol Behav 2006, 88:215-226.

9. Adler E, Hoon MA, Mueller KL, Chandrashekar J, Ryba NJP, Zuker CS: A novel family of mammalian taste receptors. Cell 2000, 100:693-702.

10. Chandrashekar J, Mueller KL, Hoon MA, Adler E, Feng L, Guo W, Zuker CS, Ryba NJ: T2Rs function as bitter taste receptors. Cell 2000, 100:703-711.

11. Roudnitzky N, Bufe B, Thalmann S, Kuhn C, Gunn HC, Xing C, Crider BP, Behrens M, Meyerhof W, Wooding SP: Genomic, genetic, and functional dissection of bitter taste responses to artificial sweeteners. Hum Mol Genet 2011, 20:3437-3449.

12. Fox AL: The relationship between chemical constitution and taste. Proc Natl Acad Sci USA 1932, 18:115-120. 
13. Bufe B, Breslin PA, Kuhn C, Reed DR, Tharp CD, Slack JP, Kim UK, Drayna D, Meyerhof $\mathrm{W}$ : The molecular basis of individual differences in phenylthiocarbamide and propylthiouracil bitterness perception. Curr Biol 2005, 15:322-327.

14. Reed DR, Zhu G, Breslin PA, Duke FF, Henders AK, Campbell MJ, Montgomery GW, Medland SE, Martin NG, Wright MJ: The perception of quinine taste intensity is associated with common genetic variants in a bitter receptor cluster on chromosome 12. Hum Mol Genet 2010, 19:42784285.

15. Pronin AN, Xu H, Tang H, Zhang L, Li Q, Li X: Specific alleles of bitter receptor genes influence human sensitivity to the bitterness of aloin and saccharin. Curr Biol 2007, 17:1403-1408.

16. Fushan AA, Simons CT, Slack JP, Manichaikul A, Drayna D: Allelic polymorphism within the TAS1R3 promoter is associated with human taste sensitivity to sucrose. Curr Biol 2009, 19:1288-1293.

17. Fushan AA, Simons CT, Slack JP, Drayna D: Association between common variation in genes encoding sweet taste signaling components and human sucrose perception. Chem Senses 2010, 35:579-592.

18. Shigemura N, Shirosaki S, Sanematsu K, Yoshida R, Ninomiya Y: Genetic and molecular basis of individual differences in human umami taste perception. PLoS One 2009, 4:e6717.

19. Keller A, Zhuang H, Chi Q, Vosshall LB, Matsunami H: Genetic variation in a human odorant receptor alters odour perception. Nature 2007, 449:468472

20. Knaapila A, Zhu G, Medland SE, Wysocki CJ, Montgomery GW, Martin NG Wright MJ, Reed DR: A genome-wide study on the perception of the odorants androstenone and galaxolide. Chem Senses 2012, doi:10.1093/ chemse/bjs048.

21. Menashe I, Man O, Lancet D, Gilad Y: Different noses for different people Nat Genet 2003, 34:143-144.

22. Jaeger SR, McRae JF, Salzman Y, Williams L, Newcomb RD: A preliminary investigation into a genetic basis for cis-3-hexen-1-ol odour perception: a genome-wide association approach. Food Quality and Preference 2010, 21:121-131.

23. McRae JF, Mainland JD, Jaeger SR, Adipietro KA, Matsunami H, Newcomb RD: Genetic variation in the odorant receptor OR2J3 is associated with the ability to detect the "grassy" smelling odor, cis-3-hexen-1-ol. Chem Senses 2012, In press.

24. Eriksson N, Macpherson JM, Tung J, Hon L, Naughton B, Saxonov S, Avey L, Wojcicki A, Pe'er I, Mountain J: Web-based, participant-driven studies yield novel genetic asociations for common traits. PLOS Genet 2010, 6:e1000993.

25. Pelchat ML, Bykowski C, Duke FF, Reed DR: Excretion and perception of a characteristic odor in urine after asparagus ingestion: a psychophysical and genetic study. Chem Senses 2010, 36:9-17.

26. Kim UK, Jorgenson E, Coon H, Leppert M, Risch N, Drayna D: Positional cloning of the human quantitative trait locus underlying taste sensitivity to phenylthiocarbamide. Science 2003, 299:1221-1225.

27. Harris $\mathrm{H}$, Kalmus $\mathrm{H}$ : The measurement of taste sensitivity to phenylthiourea (P.T.C.). Annals of Eugenics 1949, 15:24-31.

28. Mennella JA, Pepino MY, Duke FF, Reed DR: Psychophysical dissection of genotype effects on human bitter perception. Chem Senses 2010, 36:161167

29. Calo C, Padiglia A, Zonza A, Corrias L, Contu P, Tepper BJ, Barbarossa IT: Polymorphisms in TAS2R38 and the taste bud trophic factor, gustin gene co-operate in modulating PROP taste phenotype. Physiol Behav 2011, 104:1065-1071.

30. Drayna D, Coon H, Kim UK, Elsner T, Cromer K, Otterud B, Baird L, Peiffer AP, Leppert M: Genetic analysis of a complex trait in the Utah Genetic Reference Project: a major locus for PTC taste ability on chromosome 7q and a secondary locus on chromosome 16p. Hum Genet 2003, 112:567572

31. Reed DR, Nanthakumar E, North M, Bell C, Bartoshuk LM, Price RA: Localization of a gene for bitter-taste perception to human chromosome 5p15. Am J Hum Genet 1999, 64:1478-1480.

32. Genick UK, Kutalik Z, Ledda M, Souza Destito MC, Souza MM, A Cirillo C, Godinot N, Martin N, Morya E, Sameshima K, et al: Sensitivity of genomewide-association signals to phenotyping strategy: the PROP-TAS2R38 taste association as a benchmark. PLoS One 2011, 6:e27745.

33. Hansen $J$, Reed DR, Wright MJ, Martin NG, Breslin PA: Heritability and genetic covariation of sensitivity to PROP, SOA, quinine $\mathrm{HCl}$, and caffeine. Chem Senses 2006, 31:403-413.
34. Mattes RD: Gustation as a determinant of ingestion: methodological issues. Am J Clin Nutr 1985, 41:672-683.

35. Leopold AC, Ardrey R: Toxic substances in plants and the food habits of early man. Science 1972, 176:512-514.

36. Breslin PA, Beauchamp GK: Suppression of bitterness by sodium: variation among bitter taste stimuli. Chem Senses 1995, 20:609-623.

37. Mennella JA, Pepino MY, Beauchamp GK: Modification of bitter taste in children. Dev Psychobiol 2003, 43:120-127.

38. Fisher JO, Mennella JA, Hughes SO, Liu Y, Mendoza PM, Patrick H: Offering "dip" promotes intake of a moderately-liked raw vegetable among preschoolers with genetic sensitivity to bitterness. J Am Diet Assoc 2011, Nov 23. [Epub ahead of print] PMID: 22112690.

39. Mennella JA, Beauchamp GK: Optimizing oral medications for children. Clin Ther 2008, 30:2120-2132.

40. Roy G (Ed): Modifying bitterness: mechanism, ingredients, and applications. Lancaster, PA: Technomic. Publishing; 1997:285-320.

41. Lipchock SV, Reed DR, Mennella JA: Exploration of the relationship between bitter receptor genotype and retrospective reports of solid medicine formulation usage among young children. Clin Ther 2012, 34:723-733.

42. Go Y, Satta Y, Takenaka O, Takahata N: Lineage-specific loss of function of bitter taste receptor genes in humans and nonhuman primates. Genetics 2005, 170:313-326.

43. Parry CM, Erkner A, le Coutre J: Divergence of T2R chemosensory receptor families in humans, bonobos, and chimpanzees. Proc Natl Acad Sci USA 2004, 101:14830-14834.

44. Wooding S: Signatures of natural selection in a primate bitter taste receptor. J Mol Evol 2012,

45. Wang $X$, Thomas SD, Zhang J: Relaxation of selective constraint and loss of function in the evolution of human bitter taste receptor genes. Hum Mol Genet 2004, 13:2671-2678.

46. Jeon TI, Zhu B, Larson JL, Osborne TF: SREBP-2 regulates gut peptide secretion through intestinal bitter taste receptor signaling in mice. $J$ Clin Invest 2008, 118:3693-3700

47. Kaji I, Karaki SI, Fukami Y, Terasaki M, Kuwahara A: Secretory effects of a luminal bitter tastant and expressions of bitter taste receptors, T2Rs, in the human and rat large intestine. Am J Physiol Gastrointest Liver Physiol 2009, 296:G971-G981.

48. Peyrot des Gachons C, Beauchamp GK, Stern RM, Koch KL, Breslin PA: Bitter taste induces nausea. Curr Biol 2011, 21:R247-R248.

49. Rozengurt E: Taste receptors in the gastrointestinal tract. I. Bitter taste receptors and alpha-gustducin in the mammalian gut. Am J Physiol Gastrointest Liver Physiol 2006, 291:G171-G177.

50. Sandell MA, Breslin PA: Variability in a taste-receptor gene determines whether we taste toxins in food. Curr Biol 2006, 16:R792-R794.

51. Tizzano M, Gulbransen BD, Vandenbeuch A, Clapp TR, Herman JP, Sibhatu HM, Churchill ME, Silver WL, Kinnamon SC, Finger TE: Nasal chemosensory cells use bitter taste signaling to detect irritants and bacterial signals. Proc Natl Acad Sci USA 2010, 107:3210-3215.

52. Boughter JD Jr, Bachmanov A: Genetics and evolution of taste. In Edited by Beauchamp GK. Edited by Firestein S. San Diego: Olfaction \& Taste. Academic Press; 2008:371-390.

53. Cox TM: The genetic consequences of our sweet tooth. Nat Rev Genet 2002, 3:481-487.

54. Mintz SW: Sweetness and power: the place of sugar in modern history. New York: Penguin; 1986.

55. McDaniel AH, Reed DR: The human sweet tooth and its relationship to obesity. In Genomics and Proteomics in Nutrition. Edited by Berndanier CD, Moustaid-Moussa N. New York: Marcel Dekker, Inc; 2004.

56. Reed DR, McDaniel AH: The human sweet tooth. BMC Oral Health 2006, 6 (Suppl 1):S17.

57. Mennella JA, Finkbeiner S, Reed DR: The proof is in the pudding: children prefer lower fat but higher sweetness than do mothers. Int J Obesity, doi:10.1038/ijo.2012.51.

58. Kuhn C, Bufe B, Winnig M, Hofmann T, Frank O, Behrens M, Lewtschenko T, Slack JP, Ward CD, Meyerhof W: Bitter taste receptors for saccharin and acesulfame K. J Neurosci 2004, 24:10260-10265.

59. Wong GT, Gannon KS, Margolskee RF: Transduction of bitter and sweet taste by gustducin. Nature 1996, 381:796-800.

60. Li X, Glaser D, Li W, Johnson WE, O'Brien SJ, Beauchamp GK, Brand JG: Analyses of sweet receptor gene (Tas1 $\mathrm{r} 2$ ) and preference for sweet stimuli in species of Carnivora. J Hered 2009, 100(Suppl 1):S90-\$100. 
61. Li X, Li W, Wang H, Cao J, Maehashi K, Huang L, Bachmanov AA, Reed DR, Legrand-Defretin V, Beauchamp GK, et al: Pseudogenization of a sweetreceptor gene accounts for cats' indifference toward sugar. PLOS Genet 2005, 1:27-35.

62. Zhao $H$, Yang JR, Xu H, Zhang J: Pseudogenization of the umami taste receptor gene Tas1r1 in the giant panda coincided with its dietary switch to bamboo. Mol Biol Evol 2010, 27:2669-2673.

63. Jiang P, Li X, Glaser D, Li W, Brand JG, Margolskee RF, Reed DR, Beauchamp GK: Major taste loss in carnivorous mammals. Proc Natl Acad Sci USA 2012, 109:4956-4961.

64. Li X, Bachmanov AA, Maehashi K, Li W, Lim R, Brand JG, Thai C, Floriano WB, Reed DR: Sweet receptor gene variation and aspartame blindness in primates and other species. Chem Senses 2011, 36:453-475.

65. Lugaz O, Pillias AM, Faurion A: A new specific ageusia: some humans cannot taste L-glutamate. Chem Senses 2002, 27:105-115.

66. Singh PB, Schuster B, Seo HS: Variation in umami taste perception in the German and Norwegian population. Eur J Clin Nutr 2010, 64:1248-1250.

67. Chen QY, Alarcon S, Tharp A, Ahmed OM, Estrella NL, Greene TA, Rucker J, Breslin PA: Perceptual variation in umami taste and polymorphisms in TAS1R taste receptor genes. Am J Clin Nutr 2009, 90:770S-779S.

68. Raliou M, Boucher Y, Wiencis A, Bezirard V, Pernollet JC, Trotier D, Faurion A, Montmayeur JP: Tas1R1-Tas1R3 taste receptor variants in human fungiform papillae. Neurosci Lett 2009, 451:217-221.

69. Raliou M, Grauso M, Hoffmann B, Schlegel-Le-Poupon C, Nespoulous C, Debat H, Belloir C, Wiencis A, Sigoillot M, Preet Bano S, et al: Human genetic polymorphisms in T1R1 and T1R3 taste receptor subunits affect their function. Chem Senses 2011, 36:527-537.

70. Raliou M, Wiencis A, Pillias AM, Planchais A, Eloit C, Boucher Y, Trotier D, Montmayeur JP, Faurion A: Nonsynonymous single nucleotide polymorphisms in human tas1r1, tas1r3, and mGluR1 and individual taste sensitivity to glutamate. Am J Clin Nutr 2009, 90:789S-799S.

71. Shigemura N, Shirosaki S, Ohkuri T, Sanematsu K, Islam AS, Ogiwara Y, Kawai M, Yoshida R, Ninomiya Y: Variation in umami perception and in candidate genes for the umami receptor in mice and humans. Am J Clin Nutr 2009, 90:764S-7695

72. Chaudhari N, Pereira E, Roper SD: Taste receptors for umami: the case for multiple receptors. Am J Clin Nutr 2009, 90:738S-742S.

73. Törnwall O, Silventoinen K, Keskitalo-Vuokko K, Perola M, Kaprio J, Tuorila H: Genetic contribution to sour taste preference. Appetite 2012, 58:687-694

74. Wise PM, Hansen JL, Reed DR, Breslin PA: Twin study of the heritability of recognition thresholds for sour and salty taste. Chem Senses 2007, 32:749-754

75. Huque T, Cowart BJ, Dankulich-Nagrudny L, Pribitkin EA, Bayley DL, Spielman Al, Feldman RS, Mackler SA, Brand JG: Sour ageusia in two individuals implicates ion channels of the ASIC and PKD families in human sour taste perception at the anterior tongue. PLoS One 2009, 4: e7347.

76. Chandrashekar J, Kuhn C, Oka Y, Yarmolinsky DA, Hummler E, Ryba NJ, Zuker CS: The cells and peripheral representation of sodium taste in mice. Nature 2010, 464:297-301.

77. Stahler F, Riedel K, Demgensky S, Neumann K, Dunkel A, Taubert A, Raab B, Behrens $M$, Raguse J-D, Hofmann $T$, et al: A role of the epithelial sodium channel in human salt taste transduction? Chemosens Percept 2008, 1:7890.

78. Beauchamp GK, Bertino M, Engelman K: Sensory basis for human salt consumption. In NIH Workshop on Nutrition and Hypertension. Edited by Horan MJ, Blaustein MP, Dunbar JB, Kachadorian W, Kaplan NM, Simopoulos AP. Biomedical Information Corporation, New York: Proceedings from a Symposium; 1985.

79. Riera CE, Vogel H, Simon SA, Damak S, le Coutre J: Sensory attributes of complex tasting divalent salts are mediated by TRPM5 and TRPV1 channels. J Neurosci 2009, 29:2654-2662.

80. Ruiz C, Gutknecht S, Delay E, Kinnamon S: Detection of $\mathrm{NaCl}$ and $\mathrm{KCl}$ in TRPV1 knockout mice. Chem Senses 2006, 31:813-820.

81. Tordoff MG: Gene discovery and the genetic basis of calcium consumption. Physiol Behav 2008, 94:649-659.

82. Faust J: A twin study of personal preferences. J Biosoc Sci 1974, 6:75-91.

83. Fernelius I: Therapeutices universalis seu medendi rationis, libri septem. Frankfurt: Andream Wechelum; 1581.

84. Blanc S, Martin C, Passilly-Degrace P, Gaillard D, Merlin J-F, Chevrot M, Besnard P: The lipid-sensor candidates CD36 and GPR120 are differentially regulated by dietary lipids in mouse taste buds: impact on spontaneous fat preference. PLoS One 2011, 6:e24014.

85. Cartoni C, Yasumatsu K, Ohkuri T, Shigemura N, Yoshida R, Godinot N, le Coutre J, Ninomiya Y, Damak S: Taste preference for fatty acids is mediated by GPR40 and GPR120. J Neurosci 2010, 30:8376-8382.

86. Galindo MM, Voigt N, Stein J, van Lengerich J, Raguse JD, Hofmann T, Meyerhof W, Behrens M: G Protein-Coupled Receptors in human fat taste perception. Chem Senses 2011, 37:123-139.

87. Laugerette F, Passilly-Degrace P, Patris B, Niot I, Febbraio M, Montmayeur JP, Besnard P: CD36 involvement in orosensory detection of dietary lipids, spontaneous fat preference, and digestive secretions. J Clin Invest 2005, 115:3177-3184.

88. Sclafani A, Ackroff K, Abumrad NA: CD36 gene deletion reduces fat preference and intake but not post-oral fat conditioning in mice. Am J Physiol Regul Integr Comp Physiol 2007, 293:R1823-R1832.

89. Sclafani A, Zukerman S, Glendinning Jl, Margolskee RF: Fat and carbohydrate preferences in mice: the contribution of alpha-gustducin and Trpm5 taste-signaling proteins. Am J Physiol Regul Integr Comp Physiol 2007, 293:R1504-R1513.

90. Reed DR: Heritable variation in fat preference. In Fat detection: taste, texture, and post-investive effects. Edited by Montmayeur JP, de Coutre J. Boca Raton: CRC Press Taylor \& Francis Group; 2010:395-416.

91. Keller KL, Liang LC, Sakimura J, May D, van Belle C, Breen C, Driggin E, Tepper BJ, Lanzano PC, Deng L, et al: Common variants in the CD36 gene are associated with oral fat perception, fat preferences, and obesity in African Americans. Obesity (Silver Spring) 2012, doi:10.1038/oby.2011.374.

92. Pepino MY, Love-Gregory L, Klein S, Abumrad NA: The fatty acid translocase gene, CD36, and lingual lipase influence oral sensitivity to fat in obese subjects. J Lipid Res 2011, 53:561-566.

93. Törnwall O, Dinnella C, Keskitalo-Vuokko K, Silventoinen K, Perola M, Monteleone E, Kaprio J, Tuorila H: Astringency perception and heritability among young Finnish twins. Chemosens Percept 2011, 4:687-694.

94. Amoore JE, Pelosi P, Forrester LJ: Specific anosmias to 5a-androst-16-en-3one and $\omega$-pentadecalactone: the urinous and musky primary odors. Chem Senses Flavour 1977, 2:401-425.

95. Plotto A, Barnes KW, Goodner KL: Specific anosmia observed for $\beta$-lonone, but not for a-lonone: significance for flavor research. J Food Sci 2006, 71: S401-\$406.

96. Ben-Arie N, Lancet D, Taylor C, Khen M, Walker N, Ledbetter DH, Carrozzo R, Patel K, Sheer D, Lehrach $H$, et al: Olfactory receptor gene cluster on human chromosome 17: possible duplication of an ancestral receptor repertoire. Hum Mol Genet 1994, 3:229-235.

97. Lancet D, Ben-Arie N: Olfactory receptors. Curr Biol 1993, 3:668-674.

98. Glusman G, Yanai I, Rubin I, Lancet D: The complete human olfactory subgenome. Genome Res 2001, 11:685-702.

99. Zozulya S, Echeverri F, Nguyen T: The human olfactory receptor repertoire. Genome Biol 2001, 2:RESEARCH0018.

100. Gilad Y, Przeworski M, Lancet D: Loss of olfactory receptor genes coincides with the acquisition of full trichromatic vision in primates. PLOS Biol 2004, 2:E5

101. Saito H, Chi Q, Zhuang H, Matsunami H, Mainland JD: Odor coding by a Mammalian receptor repertoire. Sci Signal 2009, 2:ra9.

102. Weiss J, Pyrski M, Jacobi E, Bufe B, Willnecker V, Schick B, Zizzari P, Gossage SJ, Greer CA, Leinders-Zufall T, et al: Loss-of-function mutations in sodium channel Nav1.7 cause anosmia. Nature 2011, 472:186-190.

103. Pinto JM, Thanaviratananich S, Hayes MG, Naclerio RM, Ober C: A genomewide screen for hyposmia susceptibility loci. Chem Senses 2008, 33:319329 .

doi:10.1186/2044-7248-1-9

Cite this article as: Newcomb et al:: Heritable differences in chemosensory ability among humans. Flavour 2012 1:9. 